\title{
PHYSICAL, MECHANICAL AND AERODYNAMIC PROPERTIES OF JATROPHA SEEDS
}

\author{
A. M. Mousa ${ }^{(1)}$, N. S. Elkaoud (2) and S. H. Dosoky ${ }^{(3)}$ \\ ABSTRACT
}

This study was conducted to investigate physical, mechanical and aerodynamic properties of Jatropha seeds cultivated in Egypt. The properties were determined at moisture content of Jatropha seed 8.25 $(\%, d . b$.$) . The results showed that the mean values of the \%-ages by$ weight of seed parts to whole seed was 60.84 and $39.16 \%$ for kernels and husks, respectively. The results also include the following properties; length, width, thickness, arithmetic and geometric mean diameter, sphericity, aspect ratio, mass of individual seed, thousand seed mass, true density, bulk density, porosity, surface area, specific surface area and projected area; their averages were found to be $17.28 \mathrm{~mm}, 11.06$ $\mathrm{mm}, 8.11 \mathrm{~mm}, 12.15 \mathrm{~mm}, 11.57 \mathrm{~mm}, 67.05 \%, 64.18 \%, 0.598 \mathrm{~g}, 551.1 \mathrm{~g}$, $0.713 \mathrm{~g} / \mathrm{cm}^{3}, 0.425 \mathrm{~g} / \mathrm{cm}^{3}, 39.89 \%, 421.6 \mathrm{~mm}^{2}, 3.08 \mathrm{~cm}^{2} / \mathrm{cm}^{3}$ and 154.4 $\mathrm{mm}^{2}$, respectively. The mean value of angle of repose was $0.466 \mathrm{rad}$. For the coefficient of static friction; the stainless steel surface had the lowest value (0.196) while; the Plexi-glass surface had the highest value (0.403). The highest values of the rupture force, deformation ratio, hardness and the energy needed for rupture force were $101.3 \mathrm{~N}, 0.13,105.17 \mathrm{~N} / \mathrm{mm}$ and $61.7 \mathrm{~N} . \mathrm{mm}$ while; The lowest values were $57.0 \mathrm{~N}, 0.05,99.17 \mathrm{~N} / \mathrm{mm}$ and $19.1 \mathrm{~N} . \mathrm{mm}$, respectively. The average values of terminal velocity and coefficient of drag were $14.27 \mathrm{~m} / \mathrm{s}$ and 0.30 , respectively. Also; the average value of Reynolds number was 10898 therefore; the pattern of air flow is turbulent.

Keywords: Jatropha seeds, Biodiesel, physical, mechanical and aerodynamic properties.

\section{INTRODUCTION}

J atropha is one of the renewable energy plants. Its high potential for production of biodiesel fuel from its seeds; reduces dependence on the fossil diesel and provides the country with energy security, in addition to decrease the environmental pollution from combustion of fossil fuel, Werby and Mousa (2016).

(1): Lecturer and (3): Assoc. Prof., Agric. Mach. \& Power Eng. Dept., Fac. of Agric. Eng., Al-Azhar Univ., Cairo, Egypt. E-mail: ahmed_mousa123@azhar.edu.eg

(2): Lecturer of Agric. Eng., Fac. of Agric. Eng., Al-Azhar Univ., Assiut, Egypt. 
Many authors: Awady and El-Sayed (1994), EL-Raie et al. (1996), Tayle et al. (2011) and Werby and Mousa (2016) mentioned that the knowledge of the physical, mechanical and aerodynamic properties of agricultural products are necessary and important in design of the different component of machines and equipment of processing, handling, cleaning, transporting and storage. Mohsenin (1986) mentioned that the physical properties of agricultural material such as; shape and size, volume, density, porosity and surface area are important and essential engineering data in many problems associated with design of machines or analysis of the behavior of the agricultural products in different processes.

Jatropha "J." is known with different names such as; physic nut, pinonillo, black vomit nut, purging nut (Barbados) and big purge nut, Salawu et al. (2013). The genus of Jatropha is a perennial plant that belongs to the tribe Joannesieae in the Euphorbiaceae family and contains approximately 170 known species, Kumar and Sharma (2008). Jatropha varieties which have been identified include J. curcas, J. integerrima, J. gossypifolia among others. J. curcas has been given the needed attention among the other varieties for its rich source of oil as biofuel (biodiesel), Krishnan and Paramathma (2009) C. F. Gonu et al. (2015). Pandey et al. (2012) mentioned that the J. curcas is a multipurpose small tree or large shrub and is found throughout the tropical region. J. curcas is a tropical species native to Mexico and Central America, but is widely distributed in wild or semi cultivated stands in Latin America, Africa, India and South-East Asia.

J. curcas is a drought resistant shrub or tree and produces the fruits. Fruits are in the shape of capsules (beans) and usually contain three seeds. These seeds contain various toxic components (phorbol esters, curcin, trypsin inhibitors, lectins and phytates) and are non-edible. The dry seeds contain the oil with percentage ranging from 32 to $40 \%$ by weight, Cramer (2010).

The aim of this study was to investigate physical, mechanical and aerodynamic properties of the J. curcas seeds cultivated in Egypt. These properties could be used in design and development of suitable machines and equipment of handling, transporting storage and shelling of the fruits and seeds. 


\section{MATERIALS AND METHODS}

\subsection{Sample source}

The dried Jatropha "J." curcas fruits were obtained from "Progress Arboretum” (مشتل بروجرس) in Agouza (العجوزة) - Nile Corniche (كورنيش النيل) - Cairo - Egypt. These fruits were cultivated in Governorate of Luxor. The fruits were collected from some J. curcas farms after harvesting season of 2015 via nursery owner and stored in plastic bags at ambient temperature. The J. curcas fruits were shelled manually for separating of seeds. All the experiments were carried out in the Fac. of Agric. Eng., Al-Azhar Univ., Cairo, Egypt.

\subsection{Physical properties of J. curcas seeds}

\subsubsection{Moisture content}

The moisture content of whole J. curcas seeds and their parts (kernels and husks) were determined by drying method in a hot air oven at $105^{\circ} \mathrm{C}$ for 24 hours. This test was repeated six times. The moisture content was determined by using the following equation according to, Kabutey et al. (2015).

$$
M_{C}=\frac{m_{b}-m_{a}}{m_{a}} \times 100
$$

Where; $M_{C}$ : is the moisture content of sample, $(\%, \mathrm{~d}$. b. $)$.

$m_{b}$ : is the mass of sample before heat treatment, $(\mathrm{g})$.

$m_{a}$ : is the mass of sample after heat treatment, $(\mathrm{g})$.

\subsubsection{Percentages of seed parts}

50 seeds were randomly selected and masses of individual seeds were determined using a digital electrical balance with accuracy of $0.001 \mathrm{~g}$. The kernels of seeds were separated manually (Fig. 1) and weighed to determine the percentage of seed parts (\%, by wt.) from kernel and husks to whole seed as shown in the following equations:

$$
\begin{gathered}
\text { Kernels, }(\%, \text { wt. })=\frac{\text { Mass of } \text { kernel }}{\text { Mass of seed }} \times 100 \quad \ldots \ldots \ldots \ldots \ldots \ldots \ldots \\
\text { Husks, }(\%, \text { wt. })=\frac{\text { Mass of seed }- \text { Mass of kernel }}{\text { Mass of seed }} \times 100
\end{gathered}
$$

\subsubsection{Axial dimensions of seed}

A digital Vernier-caliper with accuracy of $0.01 \mathrm{~mm}$ was used to measure the three axial dimensions of randomly selected 100 seeds. The three axial dimensions of J. curcas seed are namely length "L, in mm" (longest 
intercept), width "W, in mm" (equatorial width perpendicular to L) and thickness " $\mathrm{T}$, in mm" (breadth perpendicular to $\mathrm{L}$ and $\mathrm{W}$ ).

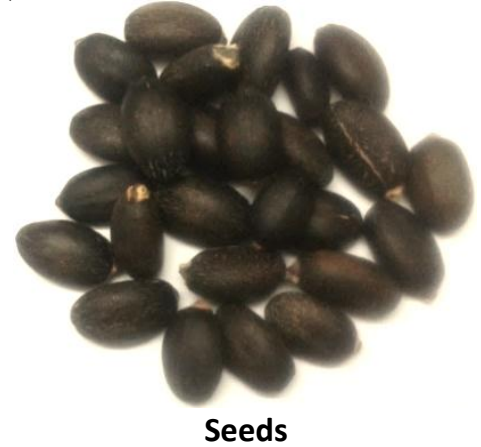

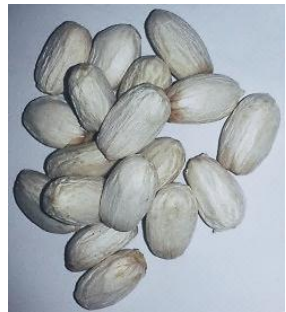

Kernels

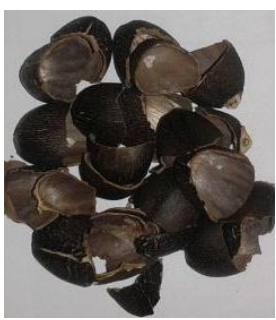

Husks

Fig. (1): Jatropha curcas seeds and their parts.

\subsubsection{Average diameter}

The average diameter of $\mathrm{J}$. curcas seed was calculated by using the arithmetic mean and geometric mean methods of the three axes dimensions. The arithmetic mean diameter (" $\mathrm{D}_{\mathrm{a}}$ ", in $\mathrm{mm}$ ) and geometric mean diameter (" $\mathrm{Dg}_{\mathrm{g}}$ ", in $\mathrm{mm}$ ) of the $\mathrm{J}$. curcas seed were calculated by using the following equations according to, Mohsenin (1986).

$$
D_{a}=\frac{L+W+T}{3} \quad \ldots \ldots(4) \quad D_{g}=(L . W . T)^{1 / 3}
$$

\subsubsection{Shape of seed}

The shapes of seeds and fruits are usually expressed in terms of their sphericity and aspect ratio according to Sahin and Sumnu (2006). The sphericity (" $\emptyset$ ", \%) of J. curcas seed was calculated by using the values of the geometric mean diameter and length according to the following equation, Mohsenin (1986).

$$
\emptyset=\frac{D_{g}}{L} \times 100
$$

The aspect ratio (" $\mathrm{R}_{\mathrm{a}}$ ", \%) of $\mathrm{J}$. curcas seed at natural flat position was calculated by using the following equations according to, Maduako and Faborode (1990) C. F. Sahin and Sumnu (2006). 
PROCESS ENGINEERING

$$
R_{a}=\frac{W}{L} \times 100
$$

\subsubsection{Mass of seeds}

To determine the mass of individual seed (" $\mathrm{M}_{\mathrm{s}}$ ", in g) a 100 was randomly selected and weighed separately using a digital electrical balance with accuracy of $0.001 \mathrm{~g}$.

To determine the thousand seed mass a $500 \mathrm{~J}$. seeds were randomly selected, then; divided to five groups (100 seeds / group) each group was

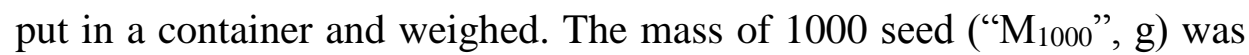
calculated from the following equation:

$$
\mathrm{M}_{1000},(\mathrm{~g})=100 \text { seed mass } \times 10 \ldots
$$

\subsubsection{True and bulk density}

The true density (" $\rho_{t}$ ", in $\mathrm{g} / \mathrm{cm}^{3}$ ) is defined as the ratio of mass of individual seed to its actual volume. The mass of individual material (100 seeds selected randomly) was determined using the digital electrical balance with accuracy of $0.001 \mathrm{~g}$ and the true volume of individual of the same seeds was determined using a method of displacement liquid. Toluene $\left(\mathrm{C}_{7} \mathrm{H}_{8}\right)$ was used instead of water because of its low absorption by the seed, its surface tension is low and its dissolution number is low. The volume of liquid displaced was found by immersing the seed in a graduated cylinder (with accuracy of $0.1 \mathrm{~cm}^{3}$ ) with known volume from the toluene. The seed was immersed in liquid with the help of a needle to push the seed into the liquid to prevent the seed from floating over the liquid. The true density was calculated using the following equation according to, Mohsenin (1986).

$$
\rho_{t}=\frac{M_{s}}{V_{t}}
$$

The bulk density (" $\rho_{b}$ ", in $\mathrm{g} / \mathrm{cm}^{3}$ ) of $\mathrm{J}$. curcas seeds was determined by putting the seeds into a $1000 \mathrm{~cm}^{3}$ graduated cylinder and weighing. To achieve uniformity in bulk density, the graduated cylinder was tapped 10 times for the seeds to consolidate according to, Bamgboye and Adebayo (2012). This process was repeated ten times and the bulk density for each replicate was calculated using the following equation:

$$
\rho_{b}=\frac{m_{s}}{v_{s}}
$$


PROCESS ENGINEERING

Where: $m_{s}$ : is the mass of J. curcas seeds, $(\mathrm{g})$.

$v_{s}$ : is the volume occupied with the seeds, $\left(\mathrm{cm}^{3}\right)$.

\subsubsection{Porosity}

The porosity (" $\varepsilon$ ", \%) of J. curcas seeds was calculated from values of bulk and true densities using the following equation according to, Mohsenin (1986).

$$
\varepsilon=\left(1-\frac{\rho_{b}}{\rho_{t}}\right) \times 100
$$

\subsubsection{Surface area and specific surface area}

Surface area is defined as the outside total area of the seed. The surface area of $\mathrm{J}$. curcas seed ("S", in $\mathrm{mm}^{2}$ ) was calculated by analogy with a sphere of the same geometric mean diameter using the following equation according to, Siqueira et al. (2013).

$$
S=\pi D_{g}^{2}
$$

The specific surface area of J. curcas seed (" $\mathrm{S}_{\mathrm{S}}$ " in $\mathrm{cm}^{2} / \mathrm{cm}^{3}$ ) was calculated using the following equation according to, Niveditha et al. (2013).

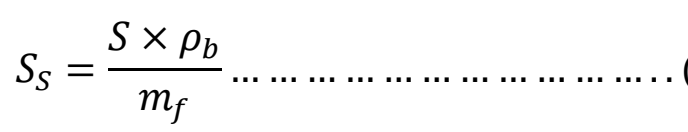

Where: $S$ : is the surface area $\left(\mathrm{cm}^{2}\right)$.

$\rho_{b}$ : is the bulk density of seeds, $\left(\mathrm{g} / \mathrm{cm}^{3}\right)$.

$m_{f}$ : is the mass of one unit of seed $(\mathrm{g})$.

\subsubsection{Projected area of seed}

$50 \mathrm{~J}$. seeds were randomly selected and were scanned using a scanner (HP Scanjet G2410) to capture the image of seeds at natural flat position, then; the pictures of seeds were exported to AutoCAD 2007 program to calculate the projected area $\left(\mathrm{A}_{\mathrm{P}}\right.$, " $\mathrm{mm}^{2}$ ") of seeds according to, Dosoky (2011) and Tayle et al. (2016).

\subsection{Mechanical properties of J. curcas seeds}

\subsubsection{Angle of repose}

The angle of repose is the angle between a horizontal surface and inclined side of the formed cone due to free fall of materials. The dynamic angle of repose of $\mathrm{J}$. curcas seeds was measured by emptying method (Werby and Mousa (2016)) to determine the dynamic angle of repose. A hollow PVC cylinder of $70 \mathrm{~mm}$ in diameter and $155 \mathrm{~mm}$ in height and a wooden table were used. The cylinder was placed on the 
wooden table. Then; it was filled with J. curcas seeds. The cylinder was raised slowly allowing the seeds to flow down to form a cone of seeds. The diameter and height of the seeds pile were measured and recorded. This experiment was repeated five times and the dynamic angle of repose for each replication was calculated using the following equation:

$$
\theta=\tan ^{-1} \frac{2 H}{D} \times \frac{\pi}{180}
$$

Where; $\theta$ : is the angle of repose, $(\mathrm{rad})$

$$
\begin{aligned}
& H: \text { is the height of the pile, }(\mathrm{cm}) \\
& D: \text { is the diameter of the pile, }(\mathrm{cm}) .
\end{aligned}
$$

\subsubsection{Coefficient of static friction}

The coefficient of static friction of J. curcas seeds was determined on five different materials namely; plywood, galvanized iron sheet (G. I. sheet), aluminum, stainless steel 304 (SS 304) and Plexi-glass. An open-ended transparent plastic cylinder having $80 \mathrm{~mm}$ internal diameter and $40 \mathrm{~mm}$ height was placed on adjustable tilting plate $(300 \mathrm{~mm} \times 175 \mathrm{~mm})$. The hollow cylinder was filled with the J. seeds, then; the cylinder was raised about $5 \mathrm{~mm}$ so as not to touch the surface. Manually; inclination of the plate was increased gradually until the filled cylinder just started to slide down, this process is according to, Werby and Mousa (2016). This experiment was repeated ten times and the coefficient of static friction for each replicate was calculated using the following equation:

$$
\mu=\tan \alpha
$$

Where: $\mu$ : is the coefficient of static friction and $\alpha$ : is the angle of friction, (degree).

\subsubsection{Rupture force, deformation ratio at rupture point, hardness and energy used for rupture.}

The rupture force is the minimum force required to break the seed. The rupture force of the $J$. curcas seed was determined using a digital universal material tester. The specifications of device were as follows: Model No: MT 20 21, range of the measurement is 0 to $20000 \mathrm{~N}$ and its accuracy is $0.1 \mathrm{~N}$. The used sample for measure the rupture force was 75 seeds. This sample was divided to three groups (25 seeds/group) for measuring the rupture force at three axial dimensions (length, width and thickness) of seed. The output data from the device was represented in a 
chart on the computer by the software of device. The chart is a relationship between the rupture force $(\mathrm{N})$ and deformation $(\mathrm{mm})$.

The deformation ratio $\left(D_{R}\right)$ is the axial strain at rupture point and it was computed using the following equation:

$$
D_{R}=\frac{d}{D}
$$

Where; $d$ : is the deformation at rapture point, (mm.).

$D$ : is the length, width or thickness of seed, (mm).

The hardness (" $\mathrm{H}$ ", $\mathrm{N} / \mathrm{mm}$ ) is the ratio of the rupture force and deformation at rupture point and it was computed using the following equation:

$$
H=\frac{R_{F}}{d}
$$

Where; $R_{F}$ : is the rupture force at rapture point, $(\mathrm{N})$.

The energy used for rupture of the seed ("E", N.mm) is equivalent to the area under the curve between the initial point and the rupture point. The area was computed by a spread sheet software program namely Microsoft Excel using some different coordinates along of the curve from origin point to rupture point.

\subsection{Aerodynamic properties of J. curcas seeds}

\subsubsection{Terminal velocity}

The terminal air velocity was measured using a terminal velocity apparatus. This apparatus was constructed according to Awady and Elsayed (1994), as shown in Fig. (2). The apparatus consisted of a rectangular tube constructed from transparent Plexi-glass and connected with the outlet of the electrical blower. The outlet of blower was covered with a wire mesh to ensure the distribution of air flow in the cross-section of the rectangular tube. A part of sheet iron was put above inlet of the blower to control in the air flow rate manually.

The seed was put on the lower screen, terminal velocity can be obtained by measuring the air velocity required to suspend the seed in the vertical air stream. Air velocity was measured at the bottom of the tube by an anemometer (range of measurement 0 to $30 \mathrm{~m} / \mathrm{s}$ with accuracy of 0.1 $\mathrm{m} / \mathrm{s}$ ). The air velocity changes with change in the cross-section of the tube. The value of the terminal velocity $\left(\mathrm{V}_{\mathrm{t}}\right)$ was calculated using the following equation: 
PROCESS ENGINEERING

$$
V_{t}=\frac{Q_{a}}{A}
$$

Where:

$\mathrm{V}_{\mathrm{t}}$ : is the terminal air velocity, $(\mathrm{m} / \mathrm{s})$.

$\mathrm{Q}_{\mathrm{a}}:$ is the air flow rate, $\left(\mathrm{m}^{3} / \mathrm{s}\right)$.

$A:$ is the cross-section area of the tube, $\left(\mathrm{m}^{2}\right)$.

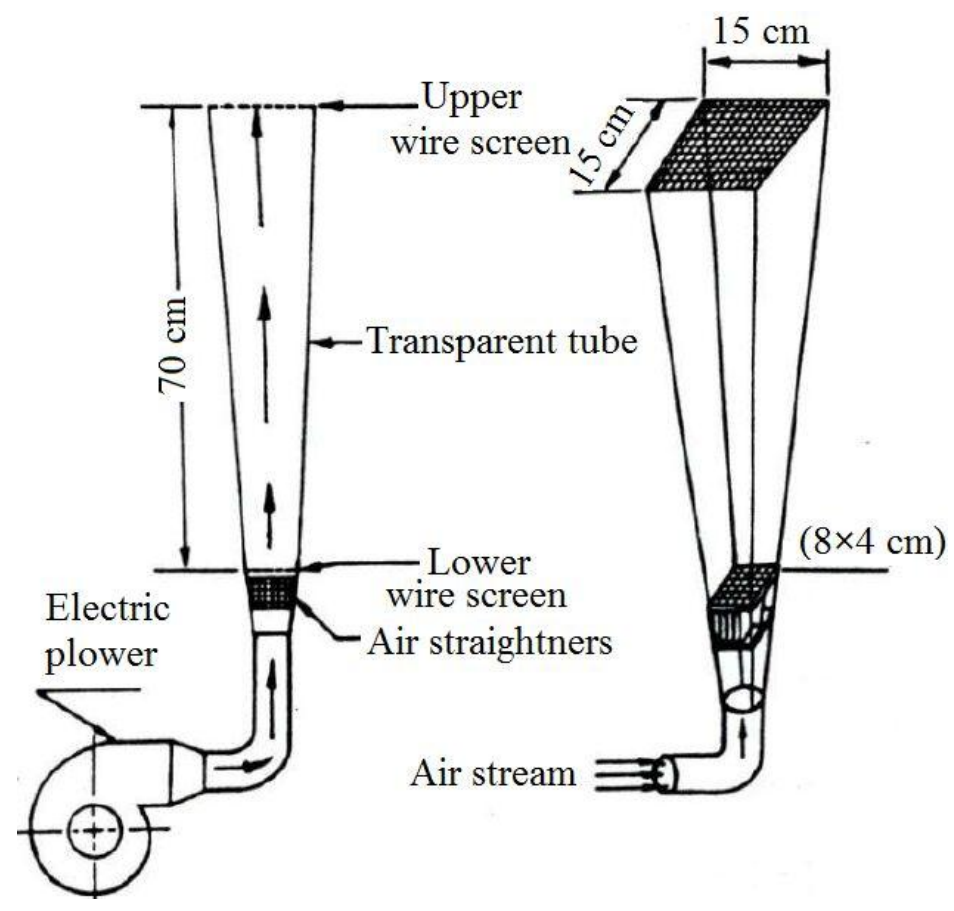

Fig. (2): Terminal air velocity apparatus, Awady and El-sayed (1994).

\subsubsection{Seed drag coefficient}

The drag coefficient of seed was calculated using the following equation according to, Mohsenin (1986).

$$
C d=\frac{2 M g}{V_{t}^{2} \times \rho_{a} \times A_{p}}
$$

Where:

$C d$ : is the coefficient of drag, (dimensionless).

$M \quad$ : is the mass of seed, $(\mathrm{kg})$.

$g$ : is the acceleration of gravity, $\left(9.81 \mathrm{~m} / \mathrm{s}^{2}\right)$.

$V_{t}$ : is the air terminal velocity, $(\mathrm{m} / \mathrm{s})$.

$\rho_{a}$ : is the air density at temperature $293 \mathrm{~K},\left(1.205 \mathrm{~kg} / \mathrm{m}^{3}\right)$.

$A_{p}:$ is the projected area of seed, $\mathrm{m}^{2}$. 
PROCESS ENGINEERING

\subsubsection{Reynolds number}

The Reynolds number was calculated using the following equation according to, Mohsenin (1986).

$$
R_{N}=\frac{\rho_{a} \times V_{t} \times D_{g}}{\mu} \ldots \ldots \ldots \ldots \ldots \ldots \ldots \ldots \ldots \ldots
$$

Where:

$R_{N}$ : is the Reynolds number, (dimensionless).

$\rho_{a}:$ is the air density at temperature $293 \mathrm{~K},\left(1.205 \mathrm{~kg} / \mathrm{m}^{3}\right)$.

$V_{t}:$ is the air terminal velocity, $(\mathrm{m} / \mathrm{s})$.

$D_{g}$ : is the geometric mean diameter of seeds, (m).

$\mu$ : is the dynamic viscosity of the air at temperature $293 \mathrm{~K}$, $\left(1.821 \times 10^{-5} \mathrm{~kg} / \mathrm{m} . \mathrm{s}\right)$.

The laminar flow is at $R_{N} \leq 2100$, turbulent flow is at $R_{N} \geq 4000$ and transitional flow at $2100<\mathrm{R}_{\mathrm{N}}<4000$, (flow in pipes).

\subsection{Statistical analysis}

The data obtained were subjected to descriptive statistics such as; range (maximum "Max" and minimum "Min"), mean, standard deviation (SD), coefficient of variation (CV), frequency distribution and coefficient of correlation by using spread sheet software program (Microsoft Excel).

\section{RESULTS AND DISCUSSIONS}

\subsection{Physical properties}

A summary of the results obtained for physical properties of J. curcas seeds are shown in Table (1).

\subsubsection{Moisture content of J. curcas seeds}

The results obtained in Table (1) showed that the moisture content of whole seeds, kernels and husks ranged from 7.99 to $8.69,6.20$ to 7.87 and 10.78 to $12.72 \%$, d. b., with the mean values \pm SD of $8.25 \pm 0.25$, $6.87 \pm 0.59$ and $11.43 \pm 0.75 \%$, d. b., respectively.

\subsubsection{Percentage of $J$. curcas seed parts}

Table (1) and Fig. (3) show the values of seed parts to whole seed, (\%, wt.). The \%-ages of kernels and husks ranged from 50.42 to 66.80 and 33.20 to $49.58 \%$ wt. and the mean values were $60.84 \pm 4.25$ and $39.16 \pm$ $4.25 \%$ wt., respectively. Thus; these results may help for determining the mass of kernels in seeds using the following equation: $\mathbf{M}_{\mathbf{k}}=\mathbf{0 . 6 0 8 4} \mathbf{M}_{\mathbf{s}}$ where: $M_{k}$; is the mass of kernels and $M_{s}$; is the mass of seeds. 
Table (1): Physical properties of J. curcas seeds.

\begin{tabular}{|c|c|c|c|c|c|c|}
\hline \multirow{2}{*}{ Parameter } & & \multicolumn{2}{|c|}{ Range } & \multirow{2}{*}{ Mean } & \multirow{2}{*}{ SD } & \multirow{2}{*}{$\begin{array}{l}\mathrm{CV}, \\
(\%) \\
\end{array}$} \\
\hline & & Min. & Max. & & & \\
\hline \multirow{3}{*}{$M_{C}(\%, d . b)}$. & Whole seeds & 7.99 & 8.69 & 8.25 & \pm 0.25 & 3.05 \\
\hline & Kernels & 6.20 & 7.87 & 6.87 & \pm 0.59 & 8.54 \\
\hline & Husks & 10.78 & 12.72 & 11.43 & \pm 0.75 & 6.57 \\
\hline \multirow{2}{*}{$\begin{array}{l}\% \text {-ages of seed parts, } \\
(\%, \text { by wt.). }\end{array}$} & Kernels & 50.42 & 66.80 & 60.84 & \pm 4.25 & 6.99 \\
\hline & Husks & 33.20 & 49.58 & 39.16 & \pm 4.25 & 10.86 \\
\hline \multirow{3}{*}{ Axial dimensions, (mm). } & $\mathrm{L}$ & 12.21 & 19.84 & 17.28 & \pm 1.05 & 6.06 \\
\hline & $\mathrm{W}$ & 9.61 & 12.16 & 11.06 & \pm 0.58 & 5.20 \\
\hline & $\mathrm{T}$ & 6.93 & 9.96 & 8.11 & \pm 0.50 & 6.13 \\
\hline \multirow{2}{*}{ Average diameter, (mm). } & $\mathrm{D}_{\mathrm{a}}$ & 10.38 & 13.45 & 12.15 & \pm 0.62 & 5.06 \\
\hline & $\mathrm{D}_{\mathrm{g}}$ & 10.15 & 12.72 & 11.57 & \pm 0.58 & 5.02 \\
\hline \multirow{2}{*}{ Shape, $(\%)$. } & $\emptyset$ & 62.18 & 83.77 & 67.05 & \pm 2.28 & 3.40 \\
\hline & $\mathrm{R}_{\mathrm{a}}$ & 52.51 & 88.94 & 64.18 & \pm 3.77 & 5.88 \\
\hline \multirow{2}{*}{ Mass, (g). } & $\mathrm{M}_{\mathrm{s}}$ & 0.352 & 0.898 & 0.598 & \pm 0.12 & 20.47 \\
\hline & $\mathrm{M}_{1000}$ & 529.3 & 570.8 & 551.1 & \pm 14.84 & 2.69 \\
\hline \multirow{2}{*}{ Density, $\left(\mathrm{g} / \mathrm{cm}^{3}\right)$. } & $\rho_{t}$ & 0.572 & 0.843 & 0.713 & \pm 0.07 & 9.19 \\
\hline & $\rho_{b}$ & 0.404 & 0.455 & 0.425 & \pm 0.02 & 3.92 \\
\hline Porosity (" $\varepsilon ", \%)$ & $\varepsilon$ & 25.68 & 49.61 & 39.89 & \pm 5.70 & 14.29 \\
\hline Surface area, $\left(\mathrm{mm}^{2}\right)$. & $S$ & 323.4 & 507.9 & 421.6 & \pm 41.73 & 9.90 \\
\hline specific surface area, $\mathrm{cm}^{2} / \mathrm{c}$ & $S_{S}$ & 2.16 & 5.02 & 3.08 & \pm 0.48 & 15.70 \\
\hline Projected area, $\left(\mathrm{mm}^{2}\right)$. & $\mathrm{A}_{\mathrm{P}}$ & 118.7 & 189.9 & 154.4 & \pm 17.78 & 11.52 \\
\hline
\end{tabular}

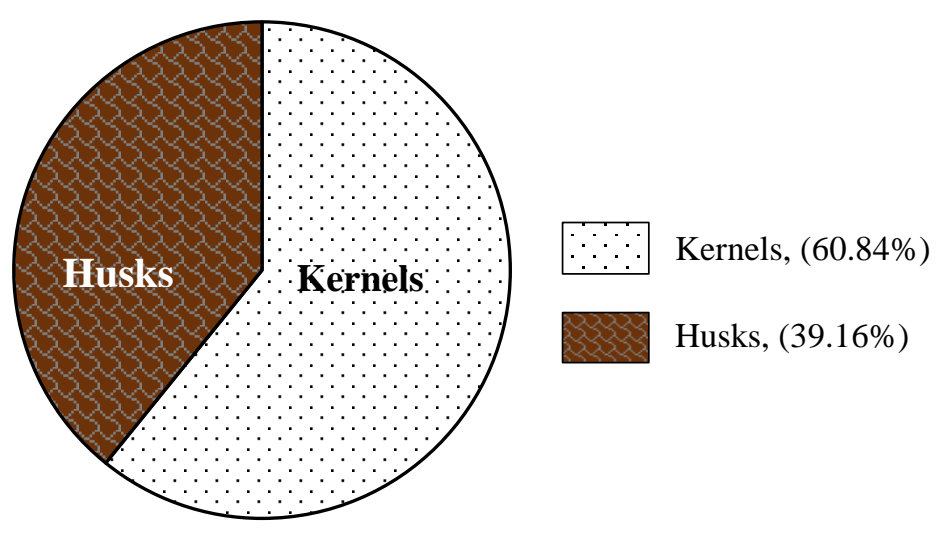

Fig. (3): Average \%-ages of kernels and husks to whole seed, $(\%, w t$.$) .$ 


\subsubsection{Axial dimensions of seed and average diameter}

Three axial dimensions of $\mathrm{J}$. curcas seeds were measured for 100 seeds. From Table (1), the values of length "L" ranged from 12.21 to19.84 mm with mean value of $17.28 \pm 1.05$ $\mathrm{mm}$, whereas; the values of width "W" ranged from 9.61 to $12.16 \mathrm{~mm}$ with mean value of $11.06 \pm 0.58$ $\mathrm{mm}$. Also; the values of thickness "T" ranged from 6.93 to $9.96 \mathrm{~mm}$ with mean value of $8.11 \pm 0.50 \mathrm{~mm}$. Fig. (4) shows the frequency distribution curves of the three axial dimensions of J. seeds (L, W and T). The highest frequencies of $\mathrm{L}, \mathrm{W}$ and $\mathrm{T}$ were $42 \%$ at $(16.58-17.67 \mathrm{~mm})$, $27 \%$ at $(10.71-11.07 \mathrm{~mm})$ and $33 \%$ at $(7.79-8.22 \mathrm{~mm})$, respectively.

The shapes of frequency distribution curves are left-skewed distribution for length, semi-normal distribution for width and right-skewed distribution for thickness.

From Table (1), the values of arithmetic mean diameter $\left(D_{a}\right)$ ranged from 10.38 to $13.45 \mathrm{~mm}$ with mean value of $12.15 \pm 0.62 \mathrm{~mm}$. Meanwhile; the values of the geometric mean diameter " $\mathrm{D}_{\mathrm{g}}$ " ranged from 10.15 to $12.72 \mathrm{~mm}$ with mean value of $11.57 \pm 0.58 \mathrm{~mm}$. Fig. (5) shows the relationship between the arithmetic and geometric mean diameter of J. curcas seeds.
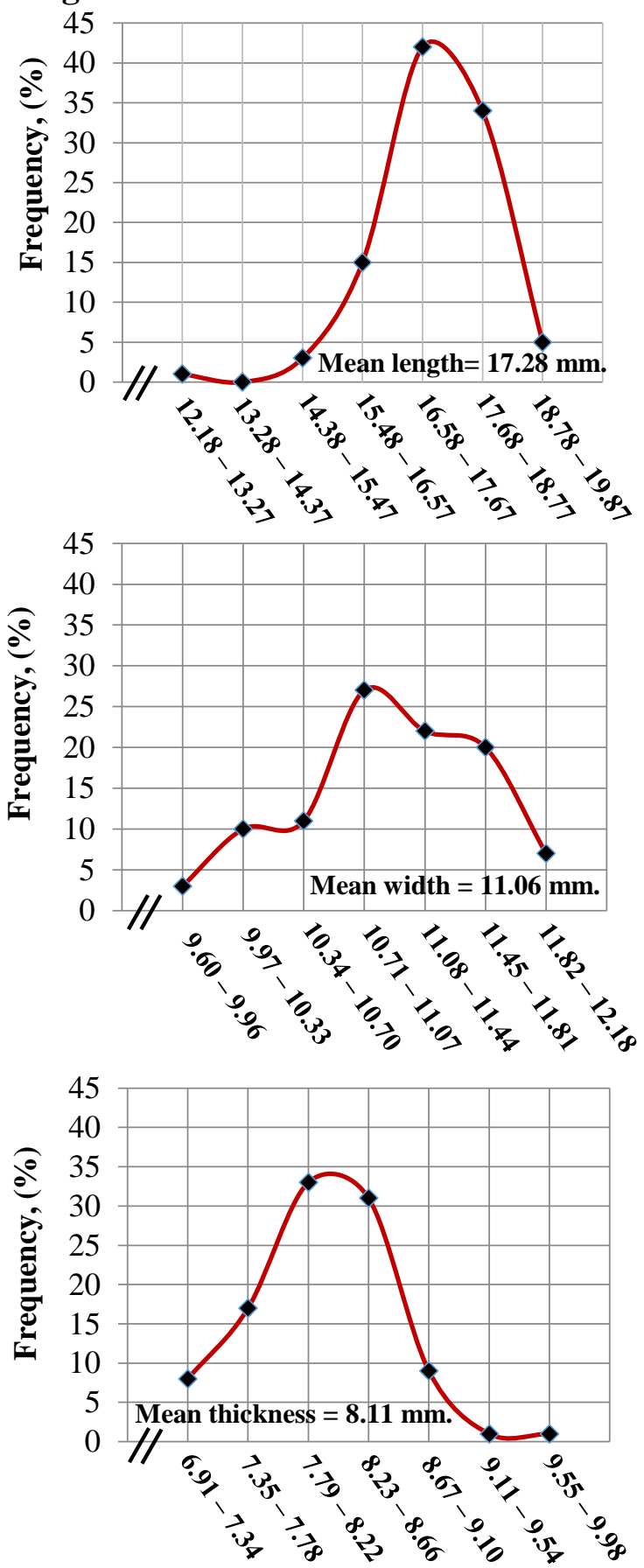

Fig. (4): Frequency distribution curves of the three axial dimensions of $\mathrm{J}$. seeds for length, width and thickness. 
This relationship indicates that the average diameters calculated by the arithmetic and the geometric mean methods were almost the same and the coefficient of correlation is very high and closer to 1 " $R=0.993$ ". So; the correlation between $\mathrm{D}_{\mathrm{a}}$ and $\mathrm{D}_{\mathrm{g}}$ is positive strong correlation as shown in Fig. (5). Therefore, either the arithmetic mean or the geometric mean method can be used to calculate the equivalent diameter of J. curcas seed.

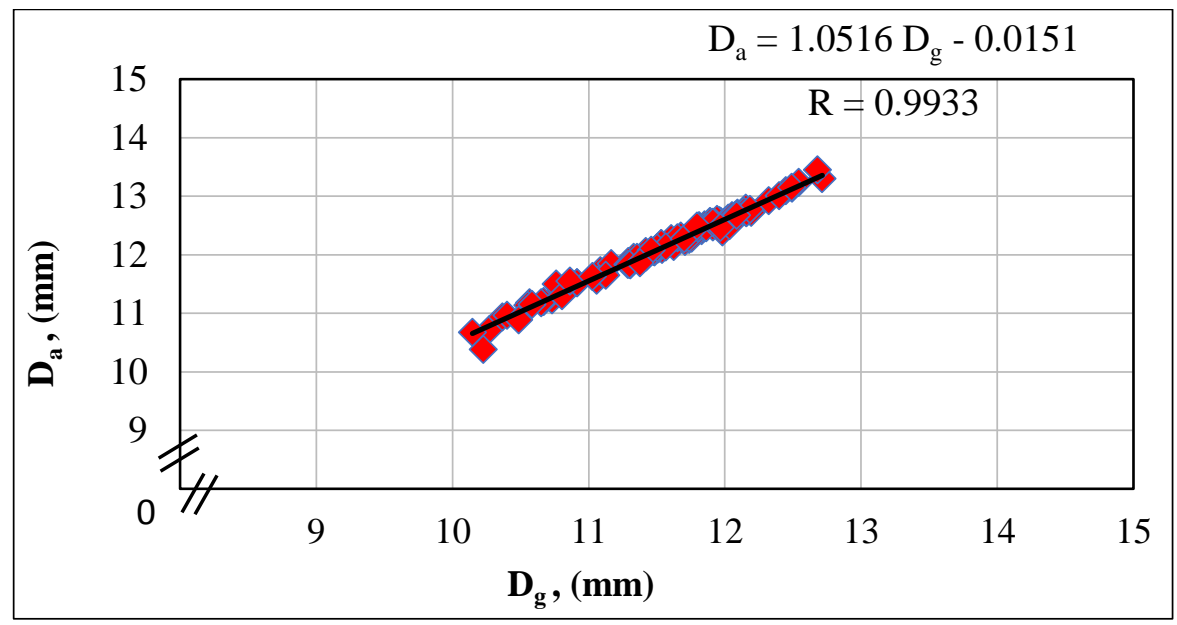

Fig. (5): Arithmetic versus geometric mean diameter of $\mathrm{J}$. curcas seeds.

The obtained results of the three axial dimensions, arithmetic mean diameter and geometric mean diameter are important to determine the range of clearance or apertures size in the shelling machines of fruit.

\subsubsection{Shape of $\mathbf{J}$. curcas seed}

The sphericity and aspect ratio were determined to express the shape of $\mathrm{J}$. curcas seed. From Table (1), the values of sphericity and aspect ratio ranged from 62.18 to 83.77 and 52.51 to $88.94 \%$ with mean values of $67.05 \pm 2.28$ and $64.18 \pm 3.77 \%$, respectively. This result is an indication that the shape of $\mathrm{J}$. curcas seed is close to the ellipsoid shape. The corresponding mean value of sphericity for J. seed by Sirisomboon et al. (2007) was $64 \pm 3 \%$ and it considered as ellipsoid shape.

\subsubsection{Mass, density and porosity of J. curcas seed}

The results showed that the values of individual seeds masses ranged from 0.352 to $0.898 \mathrm{~g}$ with mean value of $0.598 \pm 0.12 \mathrm{~g}$. Also; the results indicated that the values of the mass of one thousand seed ranged 
from 529.3 to $570.8 \mathrm{~g}$ with mean value of $551.1 \pm 14.84 \mathrm{~g}$. From Table (1) the values of true densities ranged from 0.572 to $0.843 \mathrm{~g} / \mathrm{cm}^{3}$ with mean value of $0.713 \pm 0.07 \mathrm{~g} / \mathrm{cm}^{3}$. Also; the values of bulk densities ranged from 0.404 to $0.455 \mathrm{~g} / \mathrm{cm}^{3}$ with mean value of $0.425 \pm 0.02$ $\mathrm{g} / \mathrm{cm}^{3}$. Therefore; the $\%$-ages of porosity ranged from 25.68 to 49.61 $\mathrm{g} / \mathrm{cm}^{3}$ with mean value of $39.89 \pm 5.70 \mathrm{~g} / \mathrm{cm}^{3}$.

The previous properties play an important role for determining the dimensions of storage containers, seed hopper of handling equipment and transport operations.

\subsubsection{Surface, specific surface and Projected area}

The results indicated that the values of the surface area of seeds ranged from 323.4 to $507.9 \mathrm{~mm}^{2}$ with mean value of $421.6 \pm 41.73 \mathrm{~mm}^{2}$. Meanwhile; the values of the specific surface area ranged from 2.16 to $5.02 \mathrm{~cm}^{2} / \mathrm{cm}^{3}$ with mean value of $3.08 \pm 0.48 \mathrm{~cm}^{2} / \mathrm{cm}^{3}$ as shown in Table (1). The values of projected area of seed ranged from 118.7 to $189.9 \mathrm{~mm}^{2}$ with mean value of $154.4 \pm 17.78 \mathrm{~mm}^{2}$.

\subsection{Mechanical properties:}

A summary of the results obtained for mechanical properties of J. curcas seeds are shown in Table (2).

\subsubsection{Angle of repose}

Table (2) shows the values of the dynamic angle of repose on a wooden surface. The angle of repose ranged from 0.415 to 0.518 rad with mean value $0.466 \pm 0.05 \mathrm{rad}$. This result can be used to design the side inclination of seed hopper of handling machines, silos and storage containers to allow easy sliding.

\subsubsection{Coefficient of static friction}

The coefficient of static friction of J. curcas seed against five different structural surfaces: (Plywood, G. I. sheet, aluminum, SS 304 and Plexi-glass) was determined. From Table (2), the values of coefficient of static friction ranged from 0.347 to $0.430,0.287$ to $0.333,0.261$ to 0.297 , 0.184 to 0.209 and 0.370 to 0.453 with mean values of $0.374 \pm 0.02$, $0.308 \pm 0.01,0.273 \pm 0.01,0.196 \pm 0.01$ and $0.403 \pm 0.02$; respectively. The results indicated that the SS 304 structural surface had the lowest value of the coefficient of static friction while; the Plexi-glass surface had the highest value of the coefficient of static friction as shown in Fig. (6). 
Table (2): Mechanical properties of J. curcas seeds.

\begin{tabular}{|c|c|c|c|c|c|c|}
\hline \multirow{2}{*}{ parameter } & & \multicolumn{2}{|c|}{ Range } & \multirow{2}{*}{ Mean } & \multirow{2}{*}{ SD } & \multirow{2}{*}{$\begin{array}{l}\mathrm{CV}, \\
(\%)\end{array}$} \\
\hline & & Min. & Max. & & & \\
\hline Angle of repose, $(\mathrm{rad})$ & $\theta$ & 0.415 & 0.518 & 0.466 & \pm 0.05 & 10.28 \\
\hline \multirow{5}{*}{$\begin{array}{l}\text { Coefficient of static } \\
\text { friction. }\end{array}$} & Plywood & 0.347 & 0.430 & 0.374 & \pm 0.02 & 6.18 \\
\hline & G. I. sheet & 0.287 & 0.333 & 0.308 & \pm 0.01 & 4.67 \\
\hline & Aluminum & 0.261 & 0.297 & 0.273 & \pm 0.01 & 4.22 \\
\hline & SS (304) & 0.184 & 0.209 & 0.196 & \pm 0.01 & 4.74 \\
\hline & Plexi-glass & 0.370 & 0.453 & 0.403 & \pm 0.02 & 5.82 \\
\hline \multirow{3}{*}{ Rupture force, $(\mathrm{N})$. } & $\bar{L}$ & $\begin{array}{c}50.7 \\
\end{array}$ & 12125.7 & 85.1 & \pm 20.46 & 24.05 \\
\hline & $\mathrm{W}$ & 34.5 & 78.5 & 57.0 & \pm 8.98 & 15.76 \\
\hline & $\mathrm{T}$ & 76.6 & 128.3 & 101.3 & \pm 15.71 & 15.51 \\
\hline \multirow{3}{*}{ Deformation ratio. } & L & 0.03 & 0.07 & 0.05 & \pm 0.01 & 27.62 \\
\hline & $\mathrm{W}$ & 0.03 & 0.09 & 0.05 & \pm 0.01 & 26.33 \\
\hline & $\mathrm{T}$ & 0.07 & 0.19 & 0.13 & \pm 0.03 & 23.12 \\
\hline \multirow{3}{*}{ Hardness, (N/mm) } & $\overline{\mathrm{L}}$ & $\begin{array}{l}72.40 \\
\end{array}$ & 15151.94 & $\begin{array}{l}99.17 \\
\end{array}$ & \pm 21.57 & 21.75 \\
\hline & $\mathrm{W}$ & 58.47 & 148.61 & 101.58 & \pm 21.77 & 21.43 \\
\hline & $\mathrm{T}$ & 69.64 & 146.00 & 105.17 & \pm 15.84 & 15.06 \\
\hline \multirow{3}{*}{$\begin{array}{l}\text { Energy of rupture, } \\
\text { (N.mm) }\end{array}$} & $\mathrm{L}$ & 13.5 & 73.1 & 41.1 & \pm 18.42 & 44.84 \\
\hline & $\mathrm{W}$ & 8.1 & 40.9 & 19.1 & \pm 6.64 & 34.69 \\
\hline & $\mathrm{T}$ & 26.6 & 141.5 & 61.7 & \pm 28.48 & 46.16 \\
\hline
\end{tabular}

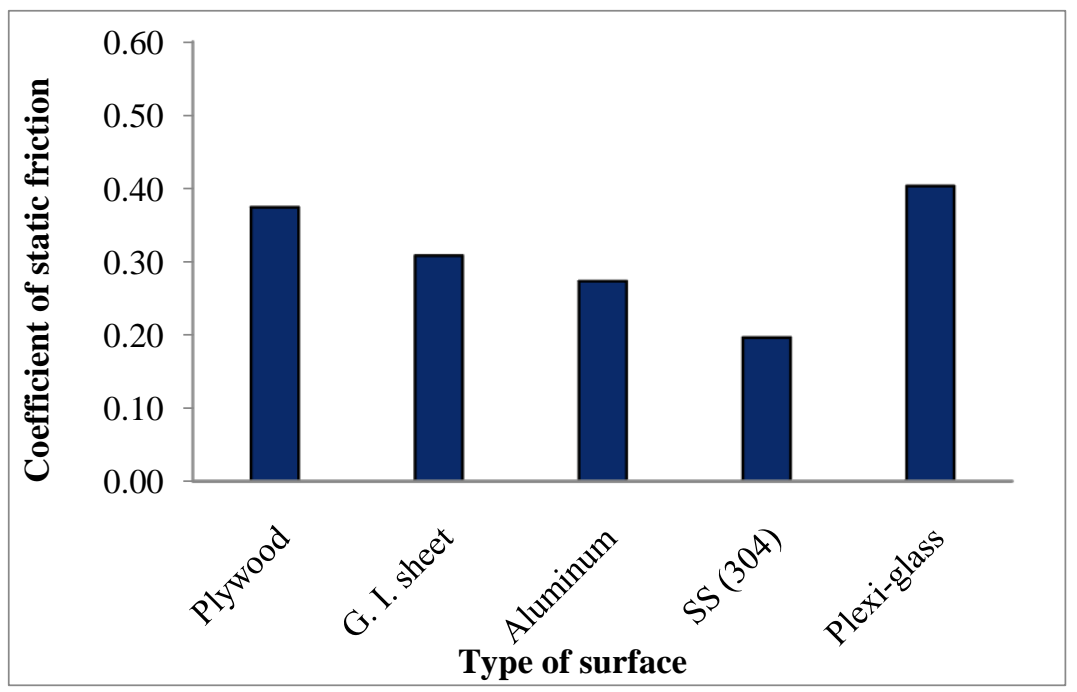

Fig. (6): Coefficient of static friction of J. curcas seed on different material surfaces. 


\subsubsection{Rupture force, deformation ratio at rupture point, hardness and energy used for rupture.}

Table (2) shows the values of the rupture force of seeds at three axial dimensions. The results showed that the rupture force ranged from 50.7 to125.7, 34.5 to 78.5 and 76.6 to $128.3 \mathrm{~N}$ with mean values of $85.1 \pm 20.46,57 \pm 8.98$ and $101.3 \pm 15.71 \mathrm{~N}$ for length, width and thickness of seed, respectively. The rupture force at loading position on the width had the lowest value followed by length while; the thickness had the highest value. Meanwhile; the deformation ratio at rupture point ranged from 0.03 to $0.07,0.03$ to 0.09 and 0.07 to 0.19 with mean values of $0.05 \pm 0.01,0.05 \pm 0.01$ and $0.13 \pm 0.03$ for length, width and thickness, respectively. The results indicated that the hardness ranged from 72.40 to $151.94,58.47$ to 148.61 and 69.64 to $146 \mathrm{~N} / \mathrm{mm}$ with mean values of $99.17 \pm 21.57,101.58 \pm 21.77$ and $105.17 \pm 15.84 \mathrm{~N} / \mathrm{mm}$ for length, width and thickness, respectively. The Energy used for rupture force ranged from 13.5 to $73.1,8.1$ to 40.9 and 26.6 to $141.5 \mathrm{~N}$.mm with mean values of $41.1 \pm 18.42,19.1 \pm 6.64$ and $61.7 \pm 28.48 \mathrm{~N}$.mm for length, width and thickness, respectively.

\subsection{Aerodynamic properties}

A summary of the results obtained for aerodynamic properties of $\mathrm{J}$. curcas seeds are shown in Table (3).

Table (3): Aerodynamic properties of J. curcas seeds.

\begin{tabular}{|c|c|c|c|c|c|c|}
\hline \multirow{2}{*}{ Parameter } & & \multicolumn{2}{|c|}{ Range } & \multirow{2}{*}{ Mean } & \multirow{2}{*}{ SD } & \multirow{2}{*}{$\begin{array}{l}\mathrm{CV}, \\
(\%)\end{array}$} \\
\hline & & Min. & Max. & & & \\
\hline Terminal velocity & $V_{t},(\mathrm{~m} / \mathrm{s})$ & 12.94 & 15.26 & 14.27 & \pm 0.51 & 3.55 \\
\hline Seed drag coefficient & $\mathrm{Cd}$ & 0.22 & 0.36 & 0.30 & \pm 0.03 & 9.09 \\
\hline Reynolds number & $\mathrm{R}_{\mathrm{N}}$ & 9506 & 12842 & 10898 & \pm 791 & 7.26 \\
\hline
\end{tabular}

The represented data in Table (3) showed that the values of terminal velocity of J. seeds ranged from 12.94 to $15.26 \mathrm{~m} / \mathrm{s}$ with mean value of $14.27 \pm 0.51 \mathrm{~m} / \mathrm{s}$. This result will help in determining the required air velocity for process of seeds separation. The results showed that the coefficient of drag ranged from 0.22 to 0.63 with mean value of $0.30 \pm$ 0.03. The values of Reynolds number ranged from 9506 to 12842 with mean value of $10898 \pm 791$. This result indicates that the pattern of air flow during the separation of seeds is turbulent. 
The previous properties of aerodynamic are useful in processes of transport and separating of seeds from any unwanted material.

\section{CONCLUSIONS}

The obtained results were summarized as follows:

The mean \%-ages of kernels and husks per whole seed were 60.84 and $39.16 \%$ by wt., respectively.

The average value of length, width, thickness, arithmetic and geometric mean diameter were $17.28,11.06,8.11,12.15$ and $11.57 \mathrm{~mm}$, respectively.

$>$ The average value of sphericity and aspect ratio were 67.05 and $64.18 \%$, respectively.

The average value of seed mass and one thousand seed were 0.598 and $551.1 \mathrm{~g}$, respectively.

$>$ The average value of true and bulk densities were 0.713 and $0.425 \mathrm{~g} / \mathrm{cm}^{3}$, respectively. In addition to the average value of porosity was $39.89 \%$.

$>$ The average values of projected and surface area were 154.4 and 421.6 $\mathrm{mm}$, respectively and the specific surface area was $3.08 \mathrm{~cm}^{2} / \mathrm{cm}^{3}$.

The mean value of angle of repose was $0.466 \mathrm{rad}$. Also; the lowest value of static friction coefficient was 0.196 for SS 304 surface. Meanwhile; the highest value was 0.403 for Plexi-glass surface.

The highest values of the rupture force, deformation ratio at rupture point, hardness and the energy were $101.3 \mathrm{~N}, 0.13,105.17 \mathrm{~N} / \mathrm{mm}$ and 61.7 N.mm while; The lowest values were $57.0 \mathrm{~N}, 0.05,99.17 \mathrm{~N} / \mathrm{mm}$ and 19.1 N.mm, respectively.

The average values of terminal velocity and coefficient of drag were $14.27 \mathrm{~m} / \mathrm{s}$ and 0.30 , respectively. Also; the average value of Reynolds number was 10898 therefore; the pattern of air flow during the separation of seeds is turbulent.

\section{REFERENCES}

Awady M. N. and A. S. El-Sayed (1994). Separation of peanut seeds by air stream. (Egypt); Misr J. Ag. Eng., 11(1): 137-147.

Bamgboye A. I. and S. E. Adebayo (2012). Seed moisture dependent on physical and mechanical properties of Jatropha curcas. (Nigeria); J. of Ag. Tec., 8(1): 13-26.

Cramer J. (2010). The Jatropha handbook from cultivation to application. (Netherlands): 2. (http://www.slideshare.net/QZ1/w1y47) 
Dosoky S. H. (2011). Physical, mechanical and aerodynamic properties of soybeans for separation and grading machines. (Egypt); The $18^{\text {th }}$. An. Conf. of the Misr Soc. of Ag. Eng., 26-27 Oct., 2011; 662 $-647$.

EL-Raie A., N. A. Hendawy and A. Z. Taib (1996). A study of physical and engineering properties for some agricultural products. (Egypt); Misr J. Ag. Eng. 13 (1): 211 - 236.

Gonu H., N. Opoku, R. Appiah-Opong, K. Joseph, M. T. Barnor and P. Quarm (2015). Phenotypic traits and chemical properties of Jatropha curcas seeds from northern Ghana. European Scientific Journal, 11(9): 327 - 340.

http://www.mhtl.uwaterloo.ca/old/onlinetools/airprop/airprop.html (2016). Kabutey A., D. Herák, R. Chotěborský, R. Sigalingging and Č. Mizera (2015). Effect of compression speed on energy requirement and oil yield of Jatropha curcas L. bulk seeds under linear compression, (Czech Republic); Biosys. Eng.; 136: 8 - 13.

Krishnan P. R. and M. Paramathma (2009). Potentials and Jatropha species wealth of India, Current Science 97(7): 1000-1004. (C. F. Gonu et al. (2015)).

Kumar A. and S. Sharma (2008). An evaluation of multipurpose oil seed crop for industrial uses (Jatropha curcas L.): A review. (India); Industrial Crops and Products, 28 (1): 1 - 10.

Maduako J. N. and M. O. Faborode (1990). Some physical properties of cocoa pods in relation to primary processing. Ife J. Technol., 2: 1 -

7. (C. F. Sahin \& Sumnu (2006)).

Mohsenin N. N. (1986). Physical properties of plant and animal materials. Gordon and Breach Sc. Publ., N.Y.

Niveditha V. R., K. R. Sridhar and D. Balasubramanian (2013). Physical and mechanical properties of seeds and kernels of Canavalia of coastal sand dunes. (India); IFRJ, 20 (4): 1547 - 1554.

Pandey V. C., K. Singh, J. S. Singh, A. Kumar, B. Singh and R. P. Singh (2012). Jatropha curcas: A potential biofuel plant for sustainable environmental development. (India); Renewable and Sustainable Energy Reviews 16: 2870 - 2883 
Sahin S. and S. G. Sumnu (2006). Physical properties of foods. USA, Springer, Handbook: 3 - 6.

Salawu A. T., M. L. Suleiman and M. Isiaka (2013). Physical properties of Jatropha curcas seed. (Nigeria); EJPAU “Agr. Eng.”; 16 (4), \# 07.

Siqueira V. C., O. Resende and T. H. Chaves (2013). Shape and size of Jatropha beans (Jatropha curcas L.) during drying at different temperatures. (Brazil); Rev. Ceres Viçosa; 60 (6): 820 - 825.

Sirisomboon P., P. Kitchaiya, T. Pholpho and W. Mahuttanyavanitch (2007). Physical and mechanical properties of Jatropha curcas L. fruits, nuts and kernels. (Thailand); Biosystem Eng., 97: $201-207$

Tayle S. A., A. K. Zaalouk, A. E. Abdelhamee and E. R. Shousha (2016). Sepration of apricotpits kernel using pneumatic system. (Egypt); Misr J. Ag. Eng., 33 (1): 195-212.

Tayle S. A., A. A. EL-Nakib, A. K. Zaalouk and A. N. Ahmed (2011). Some physical properties of apricot pits. (Egypt); Misr J. Ag. Eng., 28(1): 149-165.

Werby R. A. and A. M. Mousa (2016). Some physical and mechanical properties of Jatropha fruits. (Egypt); Misr J. Ag. Eng., 33 (2): $475-490$.

\section{الملخص العربي}

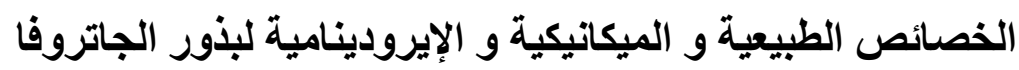

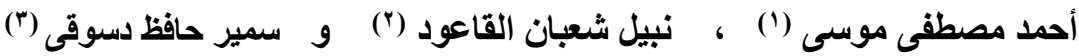

يعتبر نبات "الجاتروفا" أحد نباتات الطاقة المتجددة، حيث ينتج ثمار اً بها بذور تحتوي على نسبة عالية من الزيت الغير صالح للأكل - هذا الزيت يمكن استخدامة كمادة خام لإنتاج الديزل الحيوي بالطرق الكيميائية أو الإنزيمية - و أيضاً يمكن خلط زيت الجاتروفا بالديزل الأحفوري

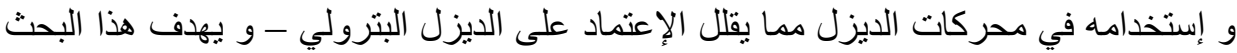
إلي توفير البيانات و المعلومات الأساسية لبذور الجاتروفا المرتبطة بتصميم آلات و معدات

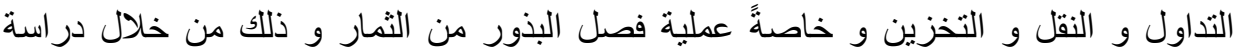

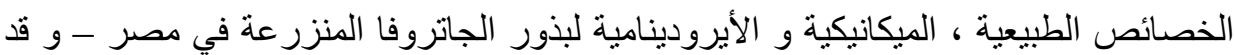

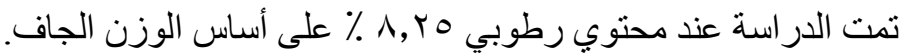

(1): مدرس و (r)): أستاذ مساعد بقسم هندسة الآلات والقوى الزراعية - كلية الهندسة الزراعية ج. الأزهر بالقاهرة - مصر. (Y) مدرس الهندسة الزراعية بكلية الهندسة الزراعية - ج. الأزهر بأسيوط - مصر. 
و كانت النتائج المتحصل عليها كالتالى :

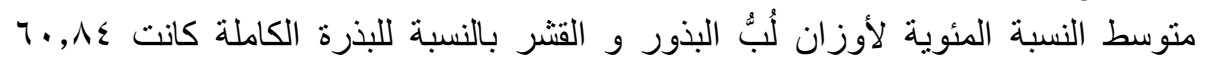

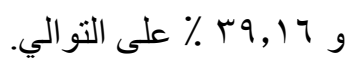

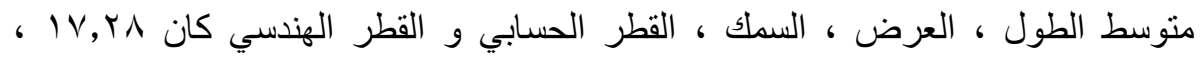

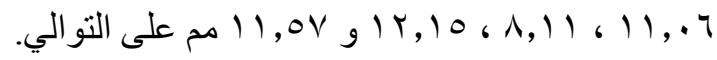

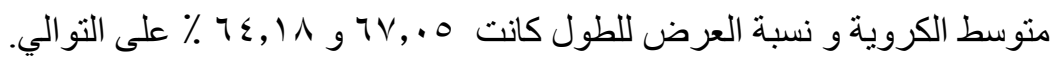

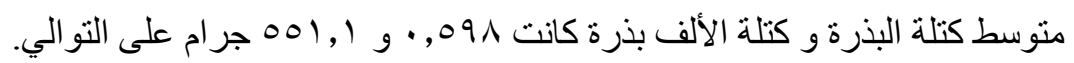

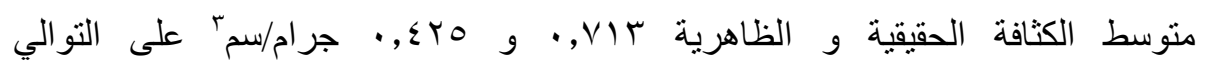

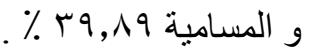

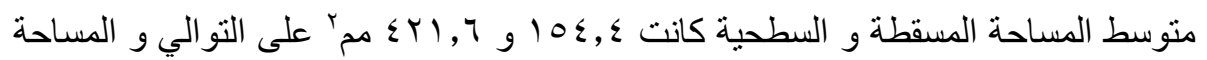

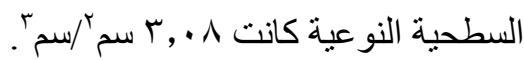

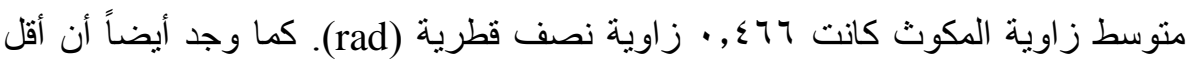
قيمة منوسطة لمعامل الإحتكاك الإستاتيكي كانت الته (SS 304) و أعلى قيمة كانت ب . ــ , • لسطح الأكريليك (Plexi-glass) .

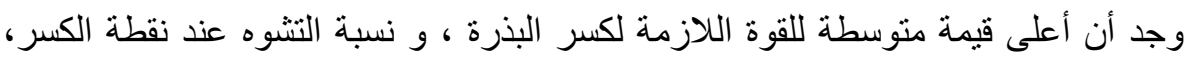

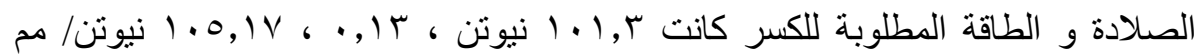

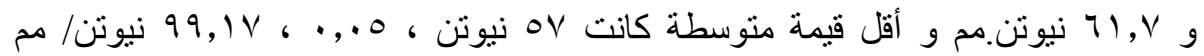
و و 19,1 نيوتن.مم على التو الي.

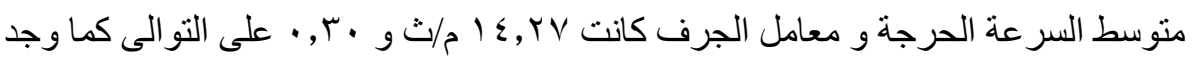

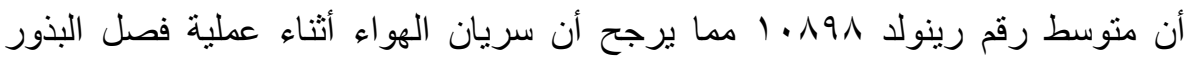
يكون مضطرب. 